\title{
Life History Trade-Offs Between Longevity and Immunity in the Parasitic Brown-Headed Cowbird?
}

\author{
D. Caldwell Hahn* and Graham W. Smith
}

USGS-Patuxent Wildife Research Center, Laurel, MD 20708-4039, USA

\begin{abstract}
Life history theory predicts evolutionary trade-offs between investing in immune defense and other traits. We investigated whether reduced longevity was associated with increased investment in immunity in an avian brood parasite, the brown-headed cowbird (Molothrus ater). Previously we had found that the brown-headed cowbird was unusually resistant to infection with West Nile virus and other pathogenic arboviruses when compared with three closely related species in the same Family, Icteridae, the New World blackbirds. In this study, we hypothesized that the cowbird's more effective immune responses may be associated with a trade-off in somatic maintenance that results in a shorter lifespan. We measured lifespan using the North American bird banding database and compared the lifespan of the cowbird with the lifespan of red-winged blackbird (Agelaius phoeniceus) and Brewer's blackbird (Euphagus cyanocephalus), two related species whose immune defenses were previously found less effective against West Nile virus. The cowbird lifespan was significantly shorter than those of both the red-winged blackbird and Brewer's blackbird. We also found that both male and female cowbirds had a shorter lifespan than the males and females in the two non-parasitic blackbird species. These data suggest that the brown-headed cowbird is a good study species for examining the trade-offs between immunity and longevity.
\end{abstract}

Keywords: Longevity, immunity, cowbird, brood parasitism, West Nile virus.

\section{INTRODUCTION}

Immunological competence is increasingly suspected to be one of the most important determinants of life-time reproductive success and fitness for many species $[1,2]$. However, the benefits of increased investment in immunity are balanced against the costs of reduced investment in other traits [3]. Increased evolutionary investment in the immune system entails changes in structure and/or mechanisms of immune defenses. Such investment may be made at the cost of investment in general somatic maintenance, which could reduce lifespan [4]. For example, Schwarzenbach and Ward [5] examined trade-offs between immunity and longevity in an artificial selection study using yellow dung flies (Scathophaga stercoraria (L.), and they demonstrated that increased genetic investment in immune system capability resulted in a trade-off with longevity. They selected for increased phenoloxidase (PO) activity, a component of insect innate defense, and found that this yielded lines of high-PO flies that died earlier than lines of low-PO flies.

We investigated the relationship between longevity and immune investment in an obligate brood parasite, the brownheaded cowbird (henceforth "cowbird")(Passeriformes, Icteridae, Molothrus spp). We selected the cowbird based on evidence that it has an unusually effective immune system. We had previously conducted a comparative study of immunity in the New World blackbirds, Icteridae [6] which consisted of experimental infection of the parasitic cowbird and three closely-related, non-parasitic blackbirds (Fig. 1) with

*Address correspondence to this author at the USGS-Patuxent Wildlife Research Center, Laurel, MD 20708-4039, USA; Tel: 301-497-5653; Fax: 301-497-5515: E-mail: chahn@usgs.gov virulent encephalitis viruses that cause illness and mortality in many avian species. We used Western equine encephalomyelitis virus (Togaviridae, Alphavirus, WEEV) and St. Louis encephalitis virus (Flaviviridae, Flavivirus, SLEV), native viruses endemic to California [7,8], and West Nile virus (Flaviviridae, Flavivirus, WNV), a particularly virulent virus that invaded North America in 1999 and California in $2003[9,10]$. The cowbird showed significantly more effective immune defenses against both native and introduced viruses than did the related non-parasitic species, exhibiting no morality, a lower rate of infection, lower levels of viremia, and faster rate of recovery [6]. This finding was supported subsequently by another experimental infection study with West Nile virus that found that the shiny cowbird $(M$. bonariensis), also an extreme host-generalist brood parasite, has enhanced immune responses similar in effectiveness to those of the brown-headed cowbird [11].

Other studies have also showed that the brown-headed cowbird is an unusually resistant species to infection [1215]. Kilpatrick et al.'s [16] review, which concluded that immunity to WNV is typically similar among species within a taxonomic Family, notably showed that the Family Icteridae had an unusual degree of immune variation: the cowbird was classified 'zero host-competence' while other Icterid species were classified with 'moderate' (Brewer's blackbird, red-winged blackbird) and 'highest' (common grackle) hostcompetence [16]. The cowbird's strong immunity is more characteristic of species in taxonomically distant orders such as parakeets (Psittaciformes), quail, chicken, pheasants (Galliformes), and rock doves (Columbiformes) than of songbird species in its own order (Passeriformes) [6]. 


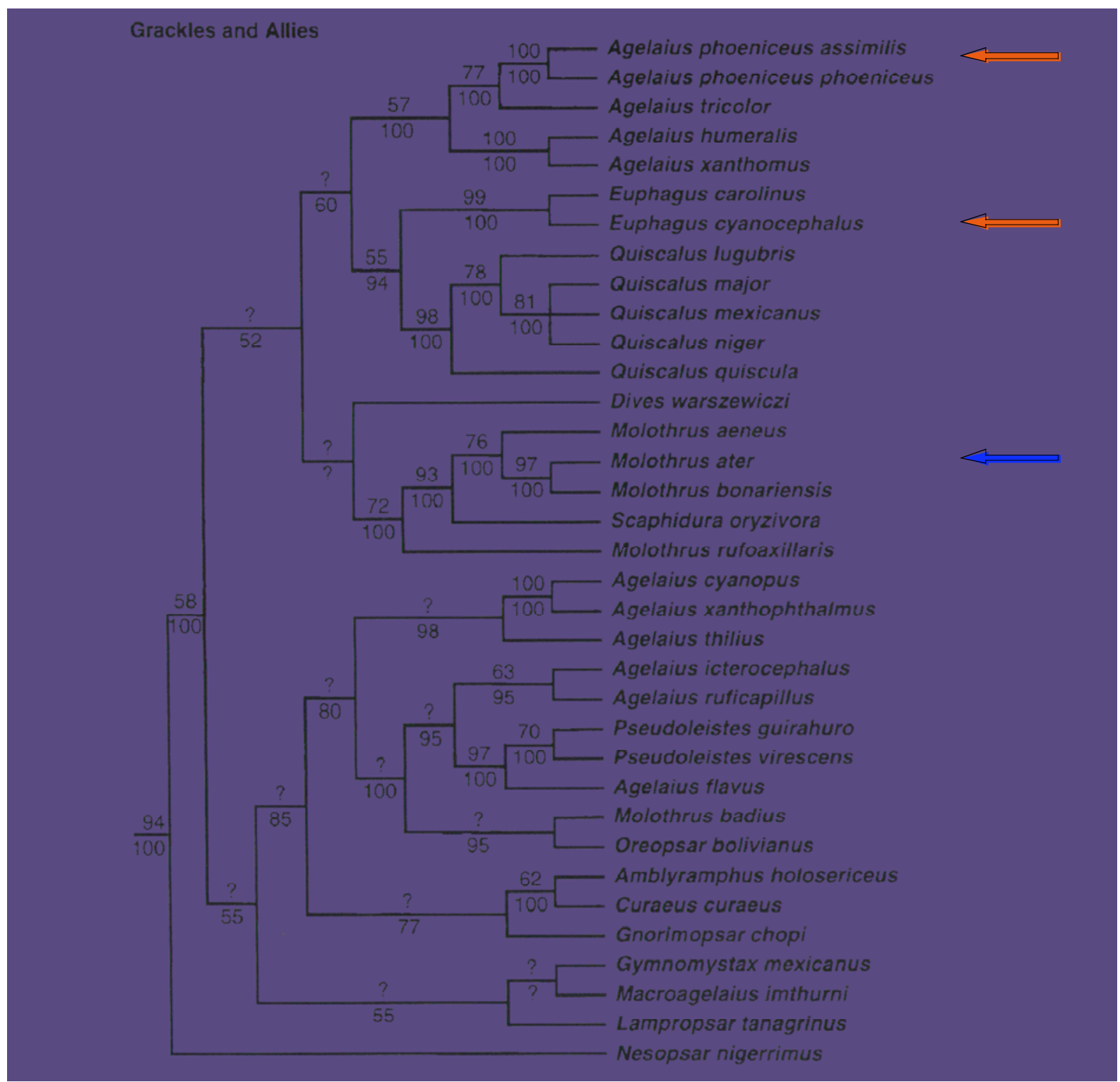

Fig. (1). Phylogeny of a sub-group of Icteridae, the grackles and allies, which include cowbirds (Molothrus spp.) and the closely related genera Agelaius spp. and Euphagus spp. Reprinted with permission from Lanyon and Omland 1999.

All cowbirds are brood parasites, but a comparative approach $[17,18]$ can be taken to studying the cowbird immune system by using non-parasitic species in sister genera. The New World blackbirds (Icteridae) are well-studied, having been used in numerous studies of avian ecology, evolution, and behavior [19-24], and the phylogeny has been established for both the cowbird genus, Molothrus [25] and the Family Icteridae [26], which includes several sister genera similar to cowbirds in most traits except brood parasitism [27].

Parasite-mediated selection [28] offers an evolutionary explanation why the cowbird has stronger immune responses than close relatives. The cowbird lays its eggs in the nests of $>225$ other avian species and never builds its own nest [29]. This life history strategy of an obligate brood parasite and, in particular, an extreme host-generalist like the brown-headed cowbird [30-32] brings cowbirds into unusual physical intimacy with diverse avian species, their nests and parasites
[33]. Parasites is used here in its widest sense, including viruses, bacteria, protists, and eukaryotes [2].

In this study we hypothesized that the cowbird's more robust immunity is associated with a trade-off in longevity. Specifically, we predicted that the cowbird would have a shorter lifespan than related, non-parasitic species with less effective immune responses. We also hypothesized that male and female cowbirds would have similar lifespans. To estimate longevity, we used bird banding records from the North American Bird Banding Lab [34], which contains $>80$ years of records. We compared the lifespan of the brown-headed cowbird with that of red-winged blackbird and Brewer's blackbird, the two related species in the same family Icteridae for which we have comparative data on immunity. There were too few banding records to include tricolored blackbird, the third blackbird species in the experimental infection study [6]. 
Table 1. Comparison of Longevity in Brown-Headed Cowbirds vs Two Related, Non-Parasitic Icterid Species with Weaker Immunity

\begin{tabular}{|c|c|c|c|c|}
\hline Species & Weight $(\mathbf{g})$ & N & Mean age (days) & 95 \% Confidence Interval (days) \\
\hline \hline Brown-headed cowbird & 44 & 2223 & 451.55 & $429.8-473.3$ \\
\hline Red-winged blackbird & 52 & 1341 & 675.37 & $639.5-711.2$ \\
\hline Brewer's blackbird & 63 & 236 & 594.19 & $512.5-675.8$ \\
\hline
\end{tabular}

\section{METHODS}

To estimate longevity, we used the large bird banding database of the Bird Banding Laboratory (BBL) at the USGS Patuxent Wildlife Research Center [34]. We drew upon records from 1923 - 2005, a time span of 83 years.

We estimated lifespan using SAS [35] to calculate the average number of days between date of banding (first record) and date of recovery ('found dead' or last record) for adults. We excluded all records in which date of recovery was inexact or where the cause of death was due to human intervention (e.g. shot, poisoned, collected for scientific purposes), because we wanted estimates of longevity based on natural mortality.

Using one-way analysis of variance, we first compared the lifespan estimates for adult brown-headed cowbirds, redwinged blackbirds, and Brewer's blackbirds with males and females together. Next, we used post-hoc tests to determine where the differences existed between species. A comparison of male vs female lifespans was done using the program CONTRAST $[36,37]$. The number of records used to compare lifespan in relation to gender (Table 2) was smaller than the number of records used to compare lifespan among species (Table 1), because some banding records lacked gender information.

\section{RESULTS}

The difference in lifespan among the cowbird, redwinged and Brewer's blackbirds was significant (Table 1) $(\mathrm{F}=20.76 ; \mathrm{p}<0.001)$. Post hoc tests showed that the lifespan of the brown-headed cowbird was significantly shorter than that of the lifespan of the red-winged blackbird $(p=0.003)$ and the Brewer's blackbird $(p=0.007)$.

The lifespan of female cowbirds was also significantly shorter than the lifespan of male cowbirds (Table 2) (CONTRAST: chi square $=20.88, \mathrm{p}<0.0001$ ), while there was no difference between male and female lifespan in either redwinged blackbird or Brewer's blackbird.

The lifespan of cowbird females was also shorter than that of female red-winged blackbirds and female Brewer's blackbirds, and the lifespan of male cowbirds was shorter than that of male red-winged blackbirds and male Brewer's blackbirds (Table 2). Thus the shorter lifespan observed for adult cowbirds vs adult red-winged and Brewer's blackbirds was not due only to the shorter lifespan of female cowbird, but to shorter lifespans of both cowbird sexes.

\section{DISCUSSION}

Longevity is influenced by many factors, not all well understood [38, 39]. Body size can influence lifespan [40], so we considered whether smaller body size could explain the cowbird's shorter lifespan. In our data, red-winged blackbird and Brewer's blackbird showed no difference in lifespan despite their being as different in size as are the cowbird and the red-winged blackbird (Table 1). Furthermore, Searcy and Yasukawa [41] analyzed the relationship between lifespan and size in seven species of Icteridae and showed that the cowbird's shorter lifespan cannot be explained by size alone. In their graph of 7 New World blackbird species (Icteridae), there is a significant relationship between wing length and lifespan for the 6 non-parasitic species, but the point designating cowbird lifespan lies significantly below the curve. The prevailing conclusion in the literature is also that only large differences in body size account for significant differences in longevity [40].

We also considered whether higher predation rate or other ecological factors could contribute to cowbird's shorter lifespan. The literature does not report that cowbirds experience higher predation than other Icterid species [29], and the three blackbird species examined in our study have similar feeding, roosting and migration behaviors; all are abundant and have large ranges [42]. In terms of mating system, brown-headed cowbirds, red-winged and Brewer's blackbirds are all polygamous [20, 43, 44] and differ primarily in the trait of brood parasitism.

Finally, we considered whether higher reproductive costs for female cowbirds could contribute to shorter lifespan. Field studies have concluded that the average number of eggs laid by cowbirds under natural conditions is similar to that laid by non-parasitic blackbirds $[45,46]$. Two laboratory

Table 2. Differences in Longevity Related to Species and Gender in Cowbirds vs Two Non-Parasitic Blackbirds with Weaker Immunity

\begin{tabular}{|c|c|c|c|c|c|c|}
\hline & \multicolumn{2}{|c|}{ All birds } & \multicolumn{2}{c|}{ Males } & \multicolumn{2}{c|}{ Females } \\
\hline & Mean age (days) (N) & SE & Mean age (days) (N) & SE & Mean age (days) (N) & SE \\
\hline \hline Brown-headed cowbird & $451.55(2223)$ & 11.11 & $537(1347)$ & 16.12 & $421.29(564)$ & 19.65 \\
\hline Red-winged blackbird & $675.37(1341)$ & 18.30 & $677.48(1209)$ & 19.31 & $652.02(145)$ & 60.18 \\
\hline Brewer's blackbird & $594.19(236)$ & 41.66 & $648.16(92)$ & 76.71 & $638.38(68)$ & 71.71 \\
\hline
\end{tabular}


studies found that female cowbirds laid a much higher number of eggs per season than non-parasitic Icterid females, although this result cannot be assumed to represent the reproductive behavior of wild cowbirds, because one study was based on ad lib food supplies, including calcium [47], and the other was based on an inference from ovarian development that has not been validated with controls [48]. Consequently, the typical number of eggs laid in a season by a female cowbird remains an unsettled question, and many investigators have observed that the cowbird's higher egglaying costs must be balanced against its lower parental care costs [32, 49]. One noteworthy consideration is that we found that male cowbirds have a shorter lifespan than males of the two non-parasitic blackbird species (Table 2), which suggests that higher egg-laying costs of females could not by itself explain the shorter adult cowbird lifespan.

The hypothesis that the cowbird's life history strategy incurs higher exposure to diverse parasites and selection for greater investment in immunity, although novel, is consistent with both theory and accumulating evidence that parasite exposure has significant costs. Parasite-mediated-selection emerged as a major principle when Hamilton and Zuk [28] predicted that parasites would be found to have far-reaching effects on species' life histories. Several investigators looking at various avian species in environments or niches with increased environmental exposure to parasites have reported elements of increased investment in immunity in various species. For example, Lindstrom et al. [50] found that populations of Darwin's finches (Geospiza fuliginosa) on larger islands with higher parasite abundance showed a higher concentration of natural antibodies and also mounted an antibody response more quickly than populations on smaller islands. Piersma [51] noted that shorebird species (Charadrii) restricted to parasite-poor breeding environments like the high arctic tundra and exposed seashores were characterized by reduced immunocompetence, based on observations that six shorebird species kept in captivity at north temperate latitudes were much more difficult to keep disease-free than other species. Blount et al. [52] found that scavenging species, which face heightened exposure to disease organisms and foreign microbes, had larger spleens than nonscavenging species as well as higher total blood leukocyte concentration. Moller and Erritzoe [53] found that holenesting birds that re-use nest sites, risking greater exposure to ectoparasites, had larger spleens and larger bursae of Fabricius than species that nest in open nests which they build new each year.

Parasite-mediated selection can be used to theorize that the cowbird's frequent exposure to foreign parasites and microbes led to more frequent infection, and this favored the evolution of greater investment in immune defenses. There is evidence that the cowbird's more effective immune defenses are based on evolutionary changes in innate immunity, since these are the cellular-level mechanisms activated and providing the first line of immune defense in the hours and days following infection with encephalitis viruses [6]. Hahn et al.'s [54] preliminary assessment of innate immune defenses in the cowbird supported this hypothesis by showing changes in cowbird immunity at the cellular level.

The cowbird's shorter lifespan could be due in part to increased costs associated with more frequent deployment of immune defenses as well as to increased evolutionary investment in immunity. Brown et al.'s [55] elegant study showed that cliff swallows (Hirundo pyrrhonota) experienced reduced annual survivorship -- equivalent to losing up to one year of lifetime reproductive success -- when immune deployment costs were increased by manipulating a higher ectoparasite load over an 8 year period. Ectoparasites have negative effects on the health and fitness of their hosts [5660]. Future work on cowbird lifespan is required to measure both the contribution of evolutionary costs of immune investment and deployment costs of immune defenses and to distinguish their relative contributions. For example, greater evolutionary investment in immunity may lower deployment costs if the mechanisms become more efficient.

\section{Gender, Immunity, and Lifespan}

We also found that the female cowbird has shorter lifespan than the male cowbird, while females did not have shorter lifespans than males in the red-winged blackbird or Brewer's blackbird (Table 2). Current work on gender differences in immunocompetence recognizes that they are the result of multiple factors associated with both endocrine differences [61-65] and life history differences [66-68]. Several studies have demonstrated that males and females invest in immunity to differently. Joop and Rolff [69] showed that female damselflies exposed to increased parasitism by water mites increased their immune response, but males did not; McKean and Nunney [70] found in Drosophila that femalebiased immune suppression resulted when food was limited, while male-biased immune suppression resulted when food was abundant and sexual activity high; Bize et al. [71] reported that, as nestlings, female alpine swifts (Apus melba) showed lower immunocompetence and higher mortality than males in response to experimentally increased ectoparasite load.

We have no data on differences in immunity of male vs female cowbirds, but if female cowbirds have higher exposure to parasites than males, they could experience greater selection for investment in immunity. Individual female cowbirds do not specialize in a particular host species, but lay their eggs in the nests of many different species [45], and thus each female is exposed to diverse ectoparasites [72] as well as other foreign microbes and parasites. Female cowbirds also explore more diverse habitats searching for nests than non-parasitic birds [73], which exposes them to more diverse insect vectors and thus to more diverse parasites [74]. Experimental infection studies comparing female vs male cowbird resistance to encephalitis viruses, especially West Nile virus, would distinguish differences in effectiveness of immune defenses between the sexes. Female cowbirds may also have higher reproductive costs than males, which could contribute to shorter lifespan, but as discussed above, the question of cowbird fecundity is not settled [45], nor is the question of evolutionary vs deployment costs of immunity.

Rolff [75] predicted that females may invest more in immunity than males based on Bateman's Principle that females increase their fitness through longevity while males increase fitness through increased mating success. However, if the life history strategy entails greater exposure to parasites for females than males, as seems likely for the brown- 
headed cowbird, then the female's greater investment in immunity may result in different life history trade-offs, including shorter lifespan.

\section{CONCLUSIONS}

One of the challenges of investigating trade-offs between immunity and longevity is that trade-offs are likely to be complex relationships among several variables [39, 76]. A good starting point is a comparative study of longevity using closely related species that differ in immunity. When correlational data like those presented here suggest a trade-off between immunity and longevity, it provides a basis for further experimental studies to examine the relationship directly. While insects are amenable to experimental studies of the effect of greater immune investment on longevity [5], longlived vertebrate species present a greater challenge. The New World cowbirds, genus Molothrus, are a good group for studying the evolution of immunity, because in addition to the presence of several sister genera similar to cowbirds in most traits except brood parasitism [27], the cowbird genus includes both extreme host-generalists (e.g. brown-headed and shiny cowbird) as well as host-specialist species, which offer a contrast in degree of exposure to other species and their parasites [11].

\section{ACKNOWLEDGEMENTS}

We thank R.E. Ricklefs, S.C. Stearns, H. Ginsberg, and two anonymous reviewers for helpful comments on the manuscript, D. Bystrak and T. Liddick for providing access to banding records, and J.E. Hines for assistance with Program Contrast.

\section{REFERENCES}

[1] Schmid-Hempel, P. Variation in immune defence as a question of evolutionary ecology. Trends Ecol. Evol., 2003, 257, 357-366.

[2] Schulenburg, H.; Kurtz, J.; Moret, Y.; Siva-Jothy, M.T. Introduction. Ecological immunology. Philos. Trans. $R$ Soc. B, 2009, 364(1513), 3-14.

[3] Sheldon, B.C.; Verhulst S. Ecological immunology: Costly parasite defences and trade-offs in evolutionary ecology. Trends Ecol. Evol., 1996, 11(8), 317-321.

[4] Kirkwood, T.B.L. Understanding the odd science of aging. Cell, 2005, 120(4), 437-447.

[5] Schwarzenbach, G.A.; Ward P.I. Responses to selection on phenoloxidase activity in yellow dung flies. Evolution, 2006, 60(8), 1612-1621.

[6] Reisen, W.K.; Hahn D.C. Comparison of immune responses of brown-headed cowbird and related blackbirds to West Nile and other mosquito-borne encephalitis viruses. J. Wildl. Dis., 2007, 43(3), 439-449.

[7] Reeves, W.C. Ed. Epidemiology and control of mosquito-borne arboviruses in California, 1943-1987. California MosquitoVector Control Association: Sacramento, CA., 1990.

[8] Reeves, W.C.; Hammon, W.M. Epidemiology of the arthropodborne viral encephalitides in Kern County, California, 1943-1952. UC Berkeley Public Health, 1962, 4, 1-257.

[9] Reisen, W.K.; Lothrop, H.; Chiles, R.; Madon, M.; Cossen, C.; Woods, L.; Husted, S.; Kramer, V.; Edman, J. West Nile virus in California. Emerg. Infect. Dis., 2004, 10, 1369-1378.

[10] Ludwig, G.V.; Calle, P.P.; Mangiafico, J.A.; Raphael, B.L.; Danner, D.K.; Hile, J.A.; Clippinger, T.L.; Smith, J.F.; Cook, R.A.; McNamara, T. An outbreak of West Nile virus in a New York City captive wildlife population. Am. J. Trop. Med. Hyg. Categories, 2002, 67(1), 67-75.

[11] Hahn, D.C.; Reisen W.K. Heightened exposure to parasites favors the evolution of immunity in brood parasitic cowbirds. Evol. Biol., 2011, 38 (2), 214-224.

[12] Reisen, W.K.; Chiles, R.E.; Kramer, L.D.; Martinez, V.M.; Eldridge, B.F. Method of infection does not alter the response of chicks and house finches to western equine encephalomyelitis and St. Louis encephalitis viruses. J. Med. Entomol., 2000, 37, 250-258.

[13] Reisen, W.K.; Chiles, R.E.;. Martinez, V.M.; Fang; Y.; Green, E.N Experimental infection of California Birds with Western Equine Encephalomyelitis and St. Louis Encephalitis Viruses. J. Med. Entomol., 2003, 40(6), 968-982.

[14] Reisen, W.K.; Fang, Y.; Martinez, V.M. Avian host and mosquito (Diptera: Culicidae) vector competence determine the efficiency of West Nile and St. Louis encephalitis virus transmission. J. Med. Entomol., 2005, 42, 367-375.

[15] Komar, N.; Langevin, S.; Hinten, S.; Nemeth, N.; Edwards, E.; Hettler, D.; Davis, B.; Bowen, R.; Bunning, M. Experimental infection of North American birds with the New York 1999 strain of West Nile virus. Emerg. Infect. Dis., 2003, 9, 311-322.

[16] Kilpatrick, A.M.; LaDeau, S.L.; Marra P.P. Ecology of west nile virus transmission and its impact on birds in the western hemisphere. Auk, 2007, 124(4), 1121-1136.

[17] Harvey, P.H.; Pagel M.S. The Comparative Method in Evolutionary Biology. Oxford Series in Ecology and Evolution, Oxford University Press: Oxford, 1991, Vol. 1.

[18] Ridley, M. The Explanation of Organic Diversity : the Comparative Method and Adaptations for Mating. Oxford University Press: Oxford, 1983, p. 272.

[19] Webster, M.S. Sexual dimorphism, mating system, and body size in New World blackbirds (Icterinae). Evolution, 1992, 46(6), 16211641

[20] Searcy, W.A.; Yasukawa, K. Polygyny and Sexual Selection in Red-Winged Blackbirds. Princeton University Press, 1995.

[21] Beletsky, L. The red-winged blackbird. The Biology of a Strongly Polygynous Songbird. Academic Press: San Diego, 1996, vol. i-ix, pp. 1-314.

[22] Beletsky, L.D.; Orians, G.H. Red-winged blackbirds: decisionmaking and reproductive success. University of Chicago Press: Chicago, 1996, vol. i-xxii, pp. 1-294.

[23] Searcy, W.A.; Yasukawa, K.; Lanyon S. Evolution of polygyny in the ancestors of red-winged blackbirds. Auk, 1999, 116(1), 5-19.

[24] Price, J.J.; Lanyon, S.M.; Omland, K.E. Losses of female song with changes from tropical to temperate breeding in the New World blackbirds. Proc. R. Soc., 2009, 276 (1664), 1971-1980.

[25] Lanyon, S.M. Interspecific brood parasitism in blackbirds (Icterinae) - a phylogenetic perspective. Science, 1992, 255(5040), 77-79.

[26] Lanyon, S.M.; Omland K.E. A molecular phylogeny of the blackbirds (Icteridae): Five lineages revealed by cytochrome-b sequence data. $A u k, 1999,116(3), 629-639$.

[27] Jaramillo, A.; Burke P. New World Blackbirds: the Icterids. Princeton, New Jersey: Princeton University Press, 1999, p. 431.

[28] Hamilton, W.H.; Zuk, M. Heritable true fitness and bright birds: a role for parasites? Science, 1982, 218, 384-387.

[29] Lowther, P.E. Brown-headed Cowbird (Molothrus ater), in The Birds of North America Poole, A, Ed. 1993, Cornell Lab of Ornithology: Ithaca, Online: http://bna.birds.cornell.edu/bna/ species/047.

[30] Johnsgard, P.A. The Avian Brood Parasites. Oxford University Press: New York, 1997, 409.

[31] Davies, N.B. Cuckoos, Cowbirds, and other Cheats. London: Poyser, 2000, p. 310

[32] Rothstein, S.I.; Robinson, S.K., Eds. Parasitic Birds and their Hosts: studies in coevolution. Oxford Ornithology Series, Oxford University Press: New York, 1998.

[33] Hahn, D.C.; Price, R.D.; Osenton, P.C. Use of lice to identify Cowbird hosts. Auk, 2000, 117(4), 943-951.

[34] Gustafson, M.E.; Hildenbrand, J. Bird Banding Laboratory Home page, ver. 07-10-2005, http://www.pwrc.usgs.gov/bbl/homepage/ introduction.htm 1999.

[35] SAS_Institute, SAS Procedures Guide. SAS Institute, Cary, N.C., 2003.

[36] Hines, J.E.; Sauer, J.R. Program CONTRAST - a general program for the analysis of several survival and recovery rate estimates. Fish Wildl. Tech. Rep., 1989, 24, 1-7.

[37] Sauer, J.R.; Williams, B.K. Generalized procedures for testing hypotheses about survival and recovery rates. J. Wildl. Manage., 1989, 53, 137-142.

[38] Williams, P.D.; Day, T.; Fletcher, Q.; Rowe, L. The shaping of senescence in the wild. Trends Ecol. Evol., 2006, 21(8), 458-463. 
[39] Ricklefs, R.E. Intrinsic aging-related mortality in birds. J. Avian Biol., 2000, 31(2), 103-111.

[40] Holmes, D.J.; Austad, S.N. Evolution of Avian Senescence. Am. Zool., 1995, 35, 307-317.

[41] Searcy, W.; Yasukawa, K. Sexual size dimorphism and survival of male and female blackbirds (Icteridae). Auk, 1981, 98, 457-465.

[42] Sauer, J.R., Hines, J.E.; Fallon, J. The North American Breeding Bird Survey, Results and Analysis, 1966-2005, v. 6.2.2006. 2005, USGS Patuxent Wildlife Research Center: Laurel, MD.

[43] Ehrlich, P.R.; Dobkin, D.S.; Wheye, D. The Birder's Handbook: a field guide to the natural history of North American birds. Simon and Schuster: New York, 1988.

[44] Alderson, G.W.; Gibbs, H.L.; Sealy S.G. Parentage and kinship studies in an obligate brood parasitic bird, the brown-headed cowbird (Molothrus ater), using microsatellite DNA markers. $J$. Hered., 1999, 90(1), 182-190.

[45] Hahn, D.C.; Sedgwick, J.A.; Painter, I.; Casna, N.J. The spatial and genetic basis of host selection, in Research and Management of the Brown-headed Cowbird in Western Landscapes. M.L. Morrison, et al. Eds. 1999, Cooper Ornithological Society: Lawrence, KS. 204217.

[46] Woolfenden, B.E.; Gibbsa, H.L.; Sealy, S.G.; McMaster, D.G. Host use and fecundity of individual female brown-headed cowbirds. Anim. Behav., 2003, 66, 95-106.

[47] Jackson, N.H.; Roby, DD. Fecundity and egg-laying patterns of captive yearling Brown-headed Cowbirds. Condor, 1992, 94(585589).

[48] Scott, D.M.; Ankney, C.D. The laying cycle of brown-headed cowbirds: passerine chickens? Auk, 1983, 100, 583-593.

[49] Ortega, C. Cowbirds and other Brood Parasites. University of Arizona Press: Tucson, AZ, 1998.

[50] Lindstrom, K.M.; Foufopoulos, J.; Pärn, H.; Wikelski, M. Immunological investments reflect parasite abundance in island populations of Darwin's finches. Proc. Royal Soc. Lond. Series BBiol. Sci., 2004, 271(1547), 1513-1519.

[51] Piersma, T. Do global patterns of habitat use and migration strategies co-evolve with relative investments in immunocompetence due to spatial variation in parasite pressure? Oikos, 1997, 80(3), 623-631.

[52] Blount, J.D.; Houston, DC.; Moller, AP.; Wright, J. Do individual branches of immune defence correlate? A comparative case study of scavenging and non-scavenging birds. Oikos, 2003, 102(2), 340350.

[53] Moller, A.P.; Erritzoe, J. Parasite virulence and host immune defense: Host immune response is related to nest reuse in birds. Evolution, 1996, 50(5), 2066-2072.

[54] Hahn, D.C.; Kogut, M.H.; Genovese, K.J.; He, H.; Summers, S.G. Ecological conditions favoring the evolution of stronger immune defenses, in European Society of Evolutionary Biology. 2009, ESEB: Turino, Italy.

[55] Brown, C.R.; Brown, M.B.; Rannala, B. Ectoparasites reduce longterm survival of their avian host. Proc. R. Soc. Lond. Ser. B-Biol. Sci., 1995, 262(1365), 313-319.

[56] Brown, C.R.; Brown, M.B. Ectoparasitism as a cost of coloniality in cliff swallows. Ecology, 1986, 67(5),1206-1218.
[57] Clayton, D.H. Mate choice in experimentally-parasitized rock doves -- lousy males lose. Am. Zool., 1990, 30, 251-262.

[58] Moller, A.P. Effects of parasitism by a hematophagous mite on Reproduction in the Barn Swallow. Ecology, 1990, 71(6), 23452357.

[59] Delope, F.; Moller, A.P. Effects of ectoparasites on reproduction of their Swallow Hosts - a cost of being Multi-Brooded. Oikos, 1993, 67(3), 557-562.

[60] Lehmann, T. Ectoparasites: direct impact on host fitness. Parasitol. Today, 1993, 9(1), 8-13.

[61] Folstad, I.; Karter, A. Parasites, bright males, and the immunocompetence handicap. Amer. Nat., 1992, 139, 603-622.

[62] Poulin, R. Cost of being male: sexual inequalities in helminth infections. 1996,

[63] Hamilton, W.J.; Poulin, R. The Hamilton and Zuk hypothesis revisited: a meta-analytical approach. Behaviour, 1997, 134, 299320.

[64] Hillgarth, N.; Ramenofsky, M.; Wingfield, J. Testosterone and sexual selection. Behav. Ecol., 1997, 8(1), 108-109.

[65] Hillgarth, N.; Wingfield, J. Parasite-Mediated Sexual Selection:Eendocrine Aspects, in Host-parasite Coevolution: General Principles and Avian Models, Clayton, D.H. and Moore. J. Eds., Oxford University Press: New York, 1997, pp. 78-104.

[66] Klein, S.L.; Nelson, R.J. Sex differences in immunocompetence differ between two Peromyscus species. Am. J. Physiol. Regul. Integr. Comp. Physiol., 1997, 42(2), R655-R660.

[67] Nelson, R.; Demas, G. Season changes in immune function. $Q$. Rev. Biol., 1996, 71(4), 511-548.

[68] Zuk, M.; McKean, K.A. Sex differences in parasite infections: patterns and processes. Int. J. Parasitol., 1996, 26(10), 1009-1024.

[69] Joop, G.; Rolff, J. Plasticity of immune function and condition under the risk of predation and parasitism. Evol. Ecol. Res., 2004, 6(7), 1051-1062

[70] McKean, K.A.; Nunney, L. Bateman's principle and immunity: Phenotypically plastic reproductive strategies predict changes in immunological sex differences. Evolution, 2005, 59(7), 1510-1517.

[71] Bize, P.; Roulin, A.; Tella, J.L.; Richner, H. Female-biased mortality in experimentally parasitized Alpine Swift Apus melba nestlings. Funct. Ecol., 2005, 19(3), 405-413.

[72] Marshall, A.G. The ecology of ectoparasitic insects. London: Academic Press, 1981

[73] Hahn, D.C.; O'Connor, R.J. Contrasting determinants of abundance in the ancestral and colonized ranges of an invasive species, in Predicting Species Occurrences: Issues of Scale and Accuracy. Scott, J.M., Heglund, P.J., and Raphael, M. Eds. Island Press. Covello, CA, 2002, pp. 219-229.

[74] Greiner, E.C.; Bennett, G.F.; White, E.M.; Coombs, R.F. Distribution of the avian hematozoa of North America. Can. J. Zool., 1975, 53, 1762-1787.

[75] Rolff, J. Bateman's principle and immunity. Proc. R. Soc. Lond. Series B-Biol. Sci., 2002, 269(1493), 867-872.

[76] Stearns, S.C. Life history evolution: successes, limitations, and prospects. Naturwissenschaften, 2000, 87, 476-486. 